\title{
"TO WORK OUT THEIR OWN SALVATION": MĀORI CONSTITUTIONALISM AND THE QUEST FOR WELFARE
}

\author{
Māmari Stephens*
}

New Zealand recently celebrated 75 years of the implementation of the welfare state in 1938. While debate continues about the nature and effectiveness of state welfare provision, welfare is arguably a matter of constitutional concern in New Zealand. Further examination of New Zealand legal history also shows that the welfare of Māori is indeed a matter of deep constitutional concern to Māori, who have consistently sought legislative and extra-legislative ways to have public power used for broad Māori welfare concerns. It is possible to identify a kind of Māori welfare constitutionalism at work, that is arguably in tension with the thinking and practice that produced the welfare state.

\section{INTRODUCTION}

In 2014 Tūhoe finally concluded its Treaty of Waitangi settlement with the Crown. ${ }^{1}$ This settlement sets the stage for an important moment in New Zealand constitutional development. One aspect of the "Mana Motuhake redress", agreed upon as an earlier part of the settlement, is a negotiated agreement that the iwi will be able to exercise a significant degree of autonomy to achieve better welfare outcomes for Tūhoe hapū and the iwi as a whole.

$\phi \quad$ Hon Ralph Hanan, Minister of Māori Affairs, regarding the enactment of the Maori Social and Economic Advancement Amendment Bill 1961: "This Bill gives the Maori people the statutory form to work out their own salvation ...": (1961) 327 NZPD 1982.

* Senior Lecturer, Victoria University of Wellington School of Law. Nō Te Rarawa, Ngāi Pākehā hoki. It is my great pleasure to offer my congratulations to Professor Bill Atkin on the publication of this issue celebrating both him and his extraordinary and wide-ranging work, including his own writings on New Zealand social security law. E te ahorangi, karawhiua tonu!

1 Tūhoe me Te Uru Taumatua rāua ko Te Karauna/The Crown Te Whakatauna o nā Tohe Raupata Tawhito/Deed of Settlement of Historical Claims (4 June 2013) at 153 and following. 
The relevant component, the Services Management Plan (SMP), is not a legal instrument, but a "relationship instrument from the Crown". ${ }^{2}$ The Ministries of Education, Social Development, and Business, Innovation and Employment have committed to work alongside Ngāi Tūhoe to improve the social circumstances of the Tūhoe people. ${ }^{3}$ The "social development" chapter appended to the SMP envisages Ngāi Tūhoe and the Ministry of Social Development (MSD) developing an initial five-year plan for: ${ }^{4}$

... driving forth an inclusive New Zealand where all Tūhoe people and Tūhoe communities are able to participate in the social and economic life of their communities to lead social development to achieve better futures for all New Zealanders.

The MSD's agencies will work alongside Ngāi Tūhoe to develop a welfare needs analysis to discover what welfare is for Tūhoe, with a view to shifting attitudes from benefit "dependence" to community interdependence. Ultimately, the SMP aims to develop a "Tūhoe Welfare System" founded upon whānau and hapū responsibility. ${ }^{5}$

In a country that already has a developed welfare system, the idea of developing a Tūhoe Welfare System is interesting but not at all revolutionary or unprecedented. Such a development would be one of the latest in a series of major legislative and policy initiatives Māori have instigated over the past 150 years that demonstrates the position that this article seeks to develop. Māori constitutional thought and action upholds Māori welfare as an aspiration to which Māori civic decision-making power must be directed.

In this context the term "constitutional" refers not only to the formal and generally recognised institutions and laws of the New Zealand state, but also to the purposes to which constitutional power is exercised. This article looks not only to a broader New Zealand-based constitution and constitutionalism, but also to the rules and institutions created by Māori to organise Māori civic decision making for specific ends. Constitutionalism has comprised, therefore, Māori practices and

2 Social Service Taskforce Ngāi Tūhoe Service Management Plan (2012) in Tūhoe me Te Uru Taumatua rāua ko Te Karauna/The Crown Whāriki/Deed of Settlement Schedule: Documents 4.

3 At 1 .

4 At 32 and 40 .

5 For analysis and description of the entire settlement, see Rawinia Higgins "Te Wharehou o Tūhoe: The house that 'we' built"(2014) October Māori LR 7; Carwyn Jones "Tūhoe Claims Settlement Act 2014; Te Urewera Report of the Waitangi Tribunal" (2014) October Māori LR 13; and Jacinta Ruru "Te Urewera Act 2014" (2014) October Māori LR 16. See generally Māmari Stephens "A transforming dawn? The Service Management Plan"(2014) October Māori LR 21. 
behaviours designed to seek mutual recognition from Māori and the Crown of those rules and institutions, by way of what Tully describes as a "constitutional dialogue or multilogue". 6

Since the 1850s Māori have sought time and time again to establish systems and rules of decision making, representation and participation aimed at improving the physical and material well-being of large sections of the Māori population, even all Māori. Examples abound within New Zealand legislation, such as the Maori Councils Act 1900, the early drafts of what became the Maori Economic and Social Advancement Act 1945, the Maori Community Development Act 1962, along with other non-legislated initiatives. They all show that Māori welfare has long been a pre-eminent focus of engagement and dispute between the Crown and Māori for constitutional recognition.

Recent developments such as the SMP confirm that engagement is ongoing. Time and time again these efforts have struggled to make headway, as the New Zealand state has rejected, wholly, or in part, a distinctly Māori constitutional vision of the welfare of Māori people as a defined goal for the use of public power.

\section{WELFARE AND CONSTITUTIONALISM}

Although the New Zealand welfare debate is usually framed in socio-political discourse, welfare can be characterised as a constitutional matter. Certainly every state may be said to exist for the very general welfare or benefit of its citizens. ${ }^{7}$ However, a narrower sense of welfare comprising, as a minimum, the basic physical and material well-being of New Zealand's poor and disadvantaged, may be broadly described as a constitutional aspiration. ${ }^{8}$ Put another way, the welfare of the poor and disadvantaged is a matter of "felt importance" for those who frame, and are subject to, New Zealand's constitution. ${ }^{9}$ The evidence for this aspiration includes the consistent use of public power to establish and maintain longstanding components of the welfare state, such as the creation of statutory entitlement to assistance by way of the Social Security Acts 1938 and 1964, the accident compensation scheme and the legal aid scheme (among other things) as well as the review and appeal systems for those institutions. ${ }^{10}$ Also important is the ongoing political consensus that public

6 James Tully Strange Multiplicity: Constitutionalism in an Age of Diversity (Cambridge University Press, Cambridge, 1995) at 24.

7 Following Michael Waltzer Spheres of Justice (Basic Books, New York, 1983) at 64-69, cited in Sotirios A Barber Welfare and the Constitution (Princeton University Press, Princeton, 2009) at xiv.

8 Although a constitutional aspiration, New Zealand's constitutional framework cannot be easily characterised as "aspirational constitutionalism". See Mauricio García-Villegas "Law as Hope: Constitutions, Courts, and Social Change in Latin America" (2004) 16 Fla J Int'l L 133.

9 Karl Llewellyn "The Constitution as an Institution" (1934) 34 Colum L Rev 1 at 28, cited in Matthew Palmer "Using Constitutional Realism to Identify the Complete Constitution: Lessons from an Unwritten Constitution" (2006) 54 Am J Comp L 587 at 594.

10 For a very useful introduction to the major characteristics of the New Zealand social security system that is beyond the scope of this article, see Bill Atkin "Social Security Law - New Zealand" in R Blanpain (ed) 
power continues to be put to such use, although endless debate rages as to the ideal extent and efficacy of state-generated welfare provision. ${ }^{11}$ Although a constitutional aspiration, the extent to which successive governments are consequently subject to a duty to achieve a given level of welfare is not the subject of this article. ${ }^{12}$

There has been much commentary about welfare reforms of the past 25 years, and the danger many such reforms pose to the ability of poorer New Zealanders to participate fully in New Zealand society. ${ }^{13}$ Some of this commentary, locally as well as internationally, has argued that such reforms undermine the notion of the "social contract", and that social citizenship is under threat. ${ }^{14}$ This debate certainly has constitutional implications. Of course, the idea of the "social contract" is an old one, and at its root is the powerful notion that individual citizens surrendered some of their rights to autonomy (including the right to use force in resolving disputes), only in exchange for the sovereign's undertaking to extend to all citizens equally "justice, peace, and the possibility of a better life". 15

With the development of social security systems in the late-19th and early to mid-20th centuries, for example, in the United Kingdom, Europe, the United States, Australia and New Zealand, the social contract notion broadened to incorporate the idea that citizenship was not only political, whereby citizens held enforceable political rights; social citizenship meant that citizens could also

International Encyclopaedia of Laws (Kluwer Law International, The Hague, 2004) 164. Briefly stated, New Zealand's social security system is one characterised by social assistance employing flat-rate benefits to New Zealanders who fall into the usual social contingency categories such as unemployment, disability, sole parenthood and temporary incapacity due to sickness. New Zealand also employs a non-contributory form of social insurance by means of its accident compensation scheme which provides compensation and other benefits to individuals who suffer personal injury by accident, and some other limited qualifying conditions.

11 For such critique and debate, particularly with regards to recent reforms, see Welfare Working Group Reducing Long-Term Benefit Dependency: Recommendations (February 2011); Welfare Justice (The Alternative Welfare Working Group) Welfare Justice for All, Reflections and recommendations: A contribution to the welfare reform debate (Caritas, December 2010); Tony McGurk The Unravelling of the Welfare Safety Net (a report prepared by Beneficiary Advocacy Federation of New Zealand for Caritas Aotearoa New Zealand, September 2008); and Matthew Hodgson and Mike O'Brien Child Poverty and Child Well-Being: New Zealand in an International Context (Child Poverty Action Group, Auckland, July 2010).

12 Nor, therefore, is the concomitant question of the existence of welfare rights.

13 For critique of recent reforms, see for example, Jacinda Ardern's speech at the third reading of the Social Security (Benefit Categories and Work Focus) Amendment Bill (67-3): (9 April 2013) 689 NZPD 9173.

14 For example Peter Dwyer "Creeping Conditionality in the UK: From Welfare Rights to Conditional Entitlements?" (2004) 29 The Canadian Journal of Sociology 265.

15 Earl Johnson Jr "Equality before the Law and the Social Contract: When will the United States Finally Guarantee its People the Equality before the Law the Social Contract Demands" (2010) 37 Fordham Urb LJ 157 at $159-160$. 
hold social rights that could be protected as part of the social contract. After all, without food or housing, how can an individual exercise a right to vote? ${ }^{16}$

Recent welfare debates suggest, but do not analyse in particular depth, the importance of welfare within New Zealand's constitutional framework, culture and practice. This article can only make a small contribution to a New Zealand-centred discourse on welfare constitutionalism, or constitutional thought and practice pertaining to the achievement of welfare in its narrower sense. ${ }^{17}$

There is one area where different notions of welfare constitutionalism can clearly be seen in action within the New Zealand context: the Māori struggle for authority and autonomy over evolving notions of Māori welfare, both in the more general sense of societal well-being, but also in regards to the basic physical and material well-being of Māori individuals, whānau and communities. Indeed, important constitutional debates over the past century have arisen in regards to the Māori quest to use public power for such "welfare". A series of major legislative and policy changes initiated by Māori demonstrate that Māori constitutionalism incorporates Māori welfare, at the very least as an aspiration to which public power must be directed.

Clear tension continues to exist between the Māori quest to use public power for welfare ends, and the goals and objectives of the New Zealand welfare state, even as Māori seek equity within that system. Generally speaking, Māori have been excluded from the design and implementation of the social security system legislation. Even as Māori have become disproportionate users of social security benefits, Māori activism in the welfare context has been directed to seeking public power to establish collective enterprise intended to achieve Māori welfare.

New Zealand's legal and social history enables us to explore both the importance of "welfare" as a constitutional idea for Māori, and ambivalence towards the state provision of welfare support to Māori. Part III will identify how Māori have been excluded from the design and implementation of New Zealand's social security system. Parts IV and V will explore how Māori have instead been working to harness public power for a somewhat different, but still contested, vision of Māori welfare.

16 Margaret Allars "Citizenship Rights, Review Rights and Contractualism" (2001) 18 Law in Context 79 at 87.

17 Arguably, as a subset of positive constitutionalism, see Sotirios A Barber "Constitutions in Exile: Is the Constitution a Charter of Negative Liberties or a Charter of Positive Benefits? Fallacies of Negative Constitutionalism"(2006) 75 Fordham L Rev 651 at 656 and following. 


\section{EXCLUSION OF MĀORI FROM THE DESIGN OF THE WELFARE STATE}

Kāre au i te paku whakaae kia noho te toru tekau mā tahi paihēneti hei mōkai ki te penihana, Māori nei tāku e kōrero nei. 18

As generally understood, government provision aimed at achieving "welfare" incorporates the social security system of benefits, among other things. Benefit rates then become a key orthodox indicator for determining individuals' reliance upon state-provided welfare. Statistics provide a tool with which to analyse Māori welfare experiences. Māori comprise 14.9 per cent of the New Zealand population. ${ }^{19}$ As at March 2015, 34.6 per cent of all beneficiaries aged between 18-64, on all forms of social security support, were Māori. ${ }^{20}$ People who identify as Māori and receive social security assistance in New Zealand are significantly more likely to receive such assistance in the first place, and less likely to be moving away from reliance upon it. Māori, on average, also receive the support for longer periods of time than Pākehā recipients. ${ }^{21}$

However, despite the disparity there is nothing to suggest that being Māori is predictive of welfare reliance, once socio-economic status is controlled for. ${ }^{22}$ Further, such facts tell us little about how Māori have sought for so long to create and achieve better Māori welfare outcomes.

\section{A Titiro Whakamuri: Looking Back}

In the wake of the socio-economic shocks caused by the Great Depression, and building on the piecemeal provision of earlier benefits such as the Old Age Pension of 1898, the New Zealand Government in 1938 created an individualised system of entitlements to assistance. In this system the state could "stand in" for the (typically male) wage-earning labourer who, by reason of social

18 "I do not accept at all the notion that 31 percent of working-age Māori should be enslaved by being on a benefit": Te Ururoa Flavell at (2012) 684 NZPD 5514

192013 Census data on Māori population is available at Statistics New Zealand "2013 Census QuickStats about Māori" (3 December 2013) <www.stats.govt.nz>.

20 The ages of 18-64 are often referred to as "working age" years. The data referred to comes from the March 2015 national level data tables: Ministry of Social Development "Statistics: Benefit Fact Sheets: Data Tables" <www.msd.govt.nz>. These figures reveal a slight increase from 34.1 per cent in the March 2014 data, and there can be seasonal variations between quarterly data.

21 Ministry of Social Development Who uses the benefit system and for how long? (Centre for Social, Research and Evaluation, Wellington, 2010) at 15.

22 Simon Chapple "Maori Socio-Economic Disparity" (2000) 52 Political Science 101 at 114; as supported in a 2014 analysis of longitudinal data in the Christchurch Health and Development Study: see Dannette Marie, David M Fergusson and Joseph M Boden "Childhood socio-economic status and ethnic disparities in psychosocial outcomes in New Zealand" (2014) 48 Aust NZ J Psychiatry 672 at 679. This study found that by controlling for socio-economic status disparities in welfare uptake between Māori and others were largely mitigated. 
contingency, could no longer work. ${ }^{23}$ If a man lost his job, state-provided income replacement could ensure that the worker and "his" family could at least survive at a very basic level, and the worker could eventually return to economic productivity. If a woman was widowed or deserted by her spouse, the state could then "step into" the shoes of the absent male wage labourer, thereby ensuring that the family could survive and eventually return to economic productivity once the children no longer required full-time care or they themselves could enter into the labour market.

While benefits were to be administered primarily on an individual basis, there was certainly an understanding or societal vision of welfare present, as expressed by the oft-quoted long title of the Social Security Act 1938: ${ }^{24}$

An Act to provide for the Payment of Superannuation Benefits and of other Benefits destined to safeguard the People of New Zealand from Disabilities arising from Age, Sickness, Widowhood, Orphanhood, Unemployment, or other Exceptional Conditions; ... to provide such other benefits as may be necessary to maintain and promote the Health and General Welfare of the Community.

The system introduced by the 1938 Act has been consolidated and constantly amended; its expansive vision has certainly shrunk. Nevertheless, the fact that the system of social security that we now have is still recognisable as a product of that early vision is testament to a limited agreement between all the governments since the 1930s that those excluded from economic productivity by social contingencies ought to receive state support. The state is expected to continue to organise itself so as to provide a needs-based, residual welfare system to allow those in poverty to be financially sustained in a fiscally responsible and equitable manner, and for those recipients to have a degree of participation in society from which they would otherwise be excluded.

The past 30 years, in particular, have seen significant ideological battles fought over the extent, coverage and generosity of the system, including its superannuation. Yet welfare remains as a charge on the conscience of New Zealand society, and arguably, underpins a constitutional aspiration that the state ought to use public power to provide, to some degree, for the basic physical and material well-being of New Zealand's poor and disadvantaged citizens.

It took a great deal of time for Māori to fit into the very limited picture of the economically productive, individualistic social security society the designers of the system envisaged in the late1930s. Throughout the first half of the 20th century, Māori were rebuilding after the traumas of the 19th century, including land loss, internecine warfare, war against the Crown, and disease, which had decimated the population and forever changed Māori social and economic dynamics. As the Māori population increased after World War Two, yet more change ensued as a predominantly rural

23 See Māmari Stephens "The Right to Social Security" in Margaret Bedggood and Kris Gledhill (eds) Law into Action: Economic, Social and Cultural Rights in Aotearoa New Zealand (Thomson Reuters, Wellington, 2011) 127 at 132.

24 Emphasis added. 
population, with remaining ties to traditional tribal lands and social and cultural structures, transformed into a predominantly urban population, in most cases separated from land and tribal structures.

\section{B Parore and Savage}

A fascinating insight into the difficulty faced by Māori who sought to transition to Western notions of individualised economic self-management comes from an exchange of letters between the first Labour Prime Minister, Michael Joseph Savage, and Lou Parore in 1936-1937. Lou Parore, of Te Roroa and Ngā Puhi descent, was a native assessor and well known leader, fed up to the back teeth with the restrictions and impositions placed on Māori by native land laws, banking and financial transactions. In late 1936 he wrote to Savage to express some of his frustrations. He had a very clear notion of what Māori had lost in being unable to provide for their own livelihood and being forced to fit into an individualistic model: ${ }^{25}$

You will appreciate the fact, that Pakeha penetration more or less destroyed tribal organisation, without providing an adequate substitute, and that after many years of dangerous experimenting, the Maori people are stripped of their health and wealth, remaining, only bleeding stumps.

The tendency has been to disrobe the Maori of his Mana, to rob him of the soil, curb his vigor and vitality, deny him liberty and freedom, and reduce him to become a worker. Whereas after a hundred years contact with Civilised peoples, the Maori should be surrounded by wealth, but now he is more like the driftwood on the ebb-tide.

$\cdots$

At present there are no laws granting, the full rights and privileges of British subjects, to the advanced Maori, to freely put into operation all that he has learned in the development of the country. And in spite of all his theoretical and practical training, his secondary and university education, the law of old Savage peoples unable to govern themselves must be governed and protected by civilized peoples which applied to his untrained grandparents, must also apply to him. Where is the progress?

Parore was not writing about social security per se, but about his desire to engage in business, unimpeded by restrictions placed upon Māori at the time. In early 1937 Savage responded; his reply is illuminating, given his status as the primary figurehead and progenitor of the Social Security Act 1938 that was, at that time, before Parliament: ${ }^{26}$

25 Letter from Lou Parore to Michael Joseph Savage (18 November 1936), cited in David Williams Crown Policy Affecting Maori Knowledge Systems and Cultural Practices (Waitangi Tribunal, 2001) at 57.

26 Letter from Michael Joseph Savage to Lou Parore (30 December 1936, dispatched 5 January 1937), cited in Williams, above $\mathrm{n} 25$, at 58 . 
I would like to think that the time had arrived, or might soon arrive when it would be prudent to allow the Maori to manage his own affairs untrammelled by this protection but while there may be some Maoris who like yourself are versed in business technicalities, the greater number are still in need of some measure of protection.

Clearly Parore, in his statement that "there are no laws granting, the full rights and privileges of British subjects, to the advanced Maori" considered that the Crown saw Māori as merely holders of an inchoate kind of citizenship; one that had not truly been earned. In 1937, when questioned about the Labour Government's native housing policy, GP Shepherd, the Under-Secretary of Native Affairs, observed: "To put it in the broadest sense we must assimilate the Maori into useful and selfrespecting citizenship."27

The necessary implication from these comments is that Māori were not yet considered fully capable of entering into citizenship in the fullest sense of the word. Māori could not be trusted to manage money and, as primarily rural and collective populations, they did not live lives of the same standard as other New Zealanders. Thus, while Māori were to be included in the new 1938 Act on equal terms, they would not actually receive the same entitlements as other New Zealanders. ${ }^{28}$

This discrimination was not new. Under the Old Age Pension Act 1898 Māori were often deemed ineligible for support, or were granted lower levels of support on the presumption that their collective practices rendered the support less necessary. Indeed, in 1937, 92 per cent of the Māori receiving the old age pension were paid a fifth lower than their Pākehā counterparts. ${ }^{29}$ So pamphlets released in Māori at the time of the passage of the Social Security Act 1938 engendered high hopes of equal treatment, as they implied that Māori would be just as entitled as Pākehā to the benefits under the Act: ${ }^{30}$

Ko nga Maori ratou ko nga pakeha e whai mana ana ki nga oranga i whakaritea e te Ture.

It became clear that the protective ethos of the welfare state as designed in the 1930s was to be interpreted very differently for Māori than for Pākehā. Discrimination would remain by virtue of the

27 Interview with Shepard, Under-Secretary of the Native Department (Lambert, Western Pacific Health Service, February 1937), cited in Williams, above n 25, at 55.

28 For further information about the discrimination faced by Māori by way of the administration of social security legislation, see Margaret McClure A Civilised Community: A History of Social Security in New Zealand 1898-1998 (Auckland University Press in association with the Historical Branch, Department of Internal Affairs, Auckland, 1998).

29 McClure, above n 28, at 34.

30 Both Māori and Pākehā are entitled to the benefits established under the Act (author's translation): $N g \bar{a}$ utunga moni $i$ raro $i$ te ture whakap mau oranga, 1938: he pukapuka whakaatu i ngā tikanga me ngā $\bar{a}$ huatanga $i$ raro $i$ te ture whakapūmau oranga hei whakahaere mā te iwi Māori (Monetary benefits to Maoris: benefits under part II of the Social Security Act, 1938: prepared for the information of the Maori race) (Social Security Department, 1939) at 1. 
use of administrative discretion under the Social Security Act 1938. Payments to Māori would continue to be lower than those for Pākehā. Income-sharing a common practice for any collectivist society - was prohibited, and those families that carried out such practices were paid less accordingly. As Mitchell summarises: "In order to receive a European level of benefit, Maori had to live like Europeans." 31

This protective, albeit paternalistic, attitude was a hallmark of the assimilationist policies of the Crown policies towards Māori of the earlier decades of the 20th century. As David Williams and Louise Humpage identify, succeeding decades saw the imposed protection of Māori based on an assumption of inequality only to be replaced by an imposed integration of Māori based on an assumption of formal equality. But neither assimilation nor integration offered Māori the freedom to make substantive decisions about Māori welfare outcomes. ${ }^{32}$

By the time the Ministerial Advisory Committee on a Māori Perspective for the Department of Social Welfare released the Püao-te-ata-tu Report of 1986, the exclusion of Māori from the administration and implementation of the welfare system and its antecedents had been well entrenched for over half a century. ${ }^{33}$ The Committee reiterated a longstanding call for Māori to have control over decision making for Māori social well-being:

As we travelled around the country, the most consistent call we heard was for Maori people to be given

the resources to control their own programmes. We have responded to this in ways that do not discriminate against people of any culture while enabling Maori people to share and to control where applicable the allocation of resources in communities.

Indeed, Māori had been seeking that freedom, with varying degrees of success, for many decades before the 1938 legislation had even been imagined.

\section{MĀORI AS CITIZENS, MĀORI AS "THE POOR"}

In order to understand how Māori have sought to achieve a somewhat different vision of welfare for Māori, and how that might be considered a constitutional matter, it is useful to identify how Māori have also sought to exercise a distinct notion of public, or civic, decision-making power. ${ }^{34}$

31 Lindsay Mitchell Te Oranga o te Iwi Maori: A Study of Maori Economic and Social Progress (New Zealand Business Round Table, Working Paper 5, 2009) at 13.

32 See Williams, above n 25, at 58. See also Louise Humpage "Revision required: Reconciling New Zealand citizenship with Māori nationalisms" (2008) 10 National Identities 247 at 253 and following.

33 Maori Perspective Advisory Committee Puao-te-ata-tu (day break): The Report of the Ministerial Advisory Committee on a Maori Perspective for the Department of Social Welfare (Department of Social Welfare, September 1988) at [72].

34 In this article, "civic decision-making power" refers to the use of decision-making processes to affect large numbers of Māori, often outside the usual institutions of the New Zealand constitution. Māori have sought to use public power for welfare ends, but in many cases have not had the ability to see such systemic 


\section{A Māori Constitutionalism/Civic Collectivism}

I have argued elsewhere that Māori communities and collectives have developed and expressed a distinct civic whanaungatanga, or civic collectivism, that speaks to a Māori ongoing quest to use public power for purposes that benefit Māori far beyond their own immediate kin group, potentially including all Māori. ${ }^{35}$ In this context, decision-making by Māori for such civic ends usually provides for substantive collective participation and public input, by way of large gatherings and other methods of face-to-face participation, or for substantive and direct Māori public input. ${ }^{36}$

Two matters will assist us here. One is to examine briefly art 3 of the Treaty of Waitangi. The modern Māori quest to use public power to achieve welfare for Māori and social citizenship can be seen to have at least some of its genesis here. The second is to examine (also necessarily briefly) the power of the idea of Māori poverty - the necessary counterpoint to ideas of Māori welfare.

\section{B Treaty of Waitangi: Article 3 and Māori as Citizens}

The Treaty of Waitangi is not the foundation point of Māori constitutional thinking or practice, although it marks an important step in both. Article 3 of the Treaty can assist in understanding some Māori justification in seeking both autonomy in decision making regarding Māori welfare outcomes, and in identifying Māori conceptions of citizenship that may differ from universalist understandings of citizenship. The English version reads: ${ }^{37}$

In consideration thereof Her Majesty the Queen of England extends to the Natives of New Zealand Her royal protection and imparts to them all the Rights and Privileges of British Subjects.

The Māori text provides:

Hei wakaritenga mai hoki tenei mo te wakaaetanga ki te Kawanatanga o te Kuini - Ka tiakina e te Kuini

o Ingarani nga tangata maori katoa o $\mathrm{Nu}$ Tirani ka tukua ki a ratou nga tikanga katoa rite tahi ki ana mea ki nga tangata o Ingarani.

Nicole Roughan noted that the text of art 3 is usually interpreted in line with the dominant liberal conception of democratic citizenship, which is, "by definition, a matter of treating people as

recognition. Such exclusion does not render the quest to use decision-making power for such ends any less constitutional.

35 See Māmari Stephens "A Loving Excavation: Uncovering the Constitutional Culture of the Māori Demos" (2013) 25 NZULR 820.

36 See also Māmari Stephens "Māori constitutionality (and the Treaty of Waitangi)" (2013) July Māori LR 8 at 18 and following.

37 See Ministry for Culture and Heritage "Read the Treaty" (20 December 2012) New Zealand History <www.nzhistory.net.nz〉. 
individuals with equal rights under the law". ${ }^{38}$ The notion of universalist citizenship not only identifies the citizen as the holder of such rights, but presumes that the rights held by such citizens are common because they arise under the shared law of the community that shares that citizenship. Acknowledging people who might also deem themselves bound by different, or special, laws or obligations would therefore be problematic: ${ }^{39}$

To be a citizen, one had to be deemed to have the rational capacity to act in accordance with a "general will" rather than for private interest. In the historical development of the institution of citizenship, this ideal of a general will required homogeneity of citizens, with the exclusion of "groups judged not capable of adopting that general point of view".

It can, of course, be argued that Article 3 of the Treaty of Waitangi bestowed an equitable citizenship shared with the "British subjects", which is upheld and reinforced by the institutions of an equitable welfare state. However, space for a specifically Māori conception of citizenship can be identified within the Māori language version, as signed by most Māori signatories. ${ }^{40}$

In 1989 Sir Hugh Kawharu published a Māori translation that retains a clearer sense of the original Māori: ${ }^{41}$

For this agreed arrangement therefore concerning the Government of the Queen, the Queen of England will protect all the ordinary people of New Zealand and will give them the same rights and duties of citizenship as the people of England.

One important point to note as between the two versions of the Treaty of Waitangi is the use of the Māori term "tikanga" to denote "the rights and privileges" of British subjects in Kawharu's translation: ${ }^{42}$

... ka tukua ki a ratou nga tikanga katoa rite tahi ki ana mea ki nga tangata o Ingarani.

Sir Kawharu expressed his own doubts that art 3 would have been equally understood in both language versions. His footnotes to the later art 3 translation read: ${ }^{43}$

38 Will Kymlicka and Wayne Norman "Return of the Citizen: A Survey of Recent Work on Citizenship Theory" (1994) 104 Ethics 353 at 370, cited in Nicole Roughan "Te Tiriti and the Constitution: Rethinking Citizenship, Justice, Equality and Democracy" (2005) 3 NZJPIL 285 at 288.

39 Roughan, above n 38, at 290. See discussion in Iris Marion Young "Polity and Group Difference: A Critique of the Ideal of Universal Citizenship" (1989) 99 Ethics 250 at 252-254, as cited by Roughan.

40 See Roughan, above n 38, at 287.

41 Footnotes omitted. See translation and footnotes at Waitangi Tribunal "The Kawharu Translation" <www.justice.govt.nz>.

42 Emphasis added.

43 At n 10 and 11. 
10. "Rights and duties": Māori at Waitangi in 1840 refer to Hobson being or becoming a "father" for the Māori people. Certainly, this attitude has been held towards the person of the Crown down to the present day - hence the continued expectations and commitments entailed in the Treaty.

11. There is, however, a more profound problem about "tikanga". There is a real sense here of the Queen "protecting" (ie allowing the preservation of) the Māori people's tikanga (ie customs) since no Māori could have had any understanding whatever of British tikanga (ie rights and duties of British subjects.) This, then, reinforces the guarantees in article 2.

It is important to note here that the range of uses for the term "tikanga" provides another reason to doubt that Māori conceptualised the rights and duties of art 3 as relating only to English or British notions of citizenship. As shown in He Papakupu Reo Ture, the term did get used from mid to late19th century to denote Western ideas of statutory provisions, governance and rights. ${ }^{44}$ However, customary notions of tikanga denoting Māori rules and practices remained undiminished. Looking to earlier accounts, Te Mātāpunenga explains "tikanga" in the following way: ${ }^{45}$

Tikanga. Tika has an outer or surface meaning of "straight, direct, keeping a direct course", tied in with the moral connotations of justice and fairness, including notions such as "right, correct". ...

Tikanga is the nominalised form of tika. This word has connotations like "rule, plan, method", extending through a general notion of any normal or usual way of being or acting, to perhaps three sets of related but to some extent separate ideas, "reason, meaning, or purport", "custom" in a quasi-legal sense (as distinct from the more mundane meaning of "habit", for which tikanga can also be employed), and "authority, control, legal condition or criterion". These same connotations can be found for cognates of tikanga in other Eastern Polynesian languages, e.g. Rarotongan tika'anga "right, authority, the proper thing to do; decision".

The use of the term "tikanga" in art 3 is thus unlikely to have meant, to the Māori minds of the time, a purely English way of doing things, let alone English notions of rights and obligations. A Māori audience, 97 years before Parore wrote to Savage about "rights and privileges of British subjects", was unlikely to have jettisoned entirely the indigenous concepts underpinning a term such as tikanga, even before a settler government had been fully established; at a time before the institution of the Māori franchise, when Māori paper-based literacy was still only beginning and a

44 Māmari Stephens and Mary Boyce (eds) He Papakupu Reo Ture: A Dictionary of Māori Legal Terms (LexisNexis, Wellington, 2013) at 81.

45 The Mātāhauariki Research Institute based at Waikato University published their compendium of customary law references: Richard Benton, Alex Frame and Paul Meredith (eds) Te Mātāpunega: A Compendium of References to the Concepts and Institutions of Māori Customary Law (Te Mātāhauariki Research Institute, University of Waikato and Victoria University Press, Wellington, 2013) at 429. 
Māori language translation of the New Testament had only been available since $1837 .{ }^{46}$ Māori may well have seen art 3 as not only protecting their own position to ensure their status would be the same as that of the "people of England", but also ensuring the survival and development of Māori ways of doing things, thereby also strengthening the promises of art 2 which guaranteed ongoing rangatiratanga over their taonga.

Despite the probability outlined above, major commentators on the nature and extent of art 3 have presumed a mono-legal interpretation, or bypassed the Māori text entirely, as demonstrated by Sir Geoffrey Palmer in his explication of the five legal principles derived from the Treaty: ${ }^{47}$

The Third Principle, the Principle of Equality, recognises the guarantee in the

Third Article of the Treaty, of legal equality between Maori and other citizens of

New Zealand. This means that all New Zealand citizens are equal before the law.

Furthermore, the common law system is selected by the Treaty as the basis for that

equality although human rights accepted under international law are incorporated

also.

$[\ldots]$

[Thus] "rights and privileges of British Subjects" must be read to include not only the heritage of a legal tradition going back to Magna Carta but also rights which spring from New Zealand's international treaty obligations such as the International Covenant on Civil and Political Rights of 1966.

The text of art 3 is important. One of the very early constitutional events in modern Māori history allowed for a concept of citizenship that is not only protective, but perhaps also positive, confirming the Māori ways of doing things, under a Māori authority. One of those "ways of doing things" was to be, over the next century and a half, creating and using collective processes in order to assist Māori individuals and collectives to attain basic physical and material well-being; or welfare. Thus the text of the Treaty sets the early scene for two views of citizenship, and arguably, two views of welfare constitutionalism that was to become clearer in the succeeding decades.

\section{Māori as "the Poor"}

By the early 1840s the conditions for a civic collectivism existed in the north and beyond. Māori social and political organisation had changed in the early decades of the century so that iwi, while still not the primary political unit that hapū were, could cohere, when required to achieve specific purposes. This evolution, married with the growing sense of a coherent and pan-tribal Māori identity

46 Jane McRae "From Māori Oral Traditions to Print" in Penny Griffiths, Rose Harvey and Keith Maslen (eds) Books and Print in New Zealand: a Guide to Print Culture in Aotearoa, (Victoria University Press, Wellington, 1997) 30.

47 Geoffrey Palmer "The Treaty of Waitangi - principles for Crown action" (1989) 19 VUWLR 335 at 341342. 
as distinct and separate from "Pākehā", proved fertile ground for the development of the notion that hapū and iwi could have interests in common. It could be possible to make "good" decisions for one's iwi or for "Māori" rather than just for one's own immediate or closely related hapū. ${ }^{48}$

Māori began to view themselves as collectives, distinct and separate from "the Pākehā", quite early in the 19th century. As land loss increased, so too arose the notion of Māori as being "the poor". Land has been described as the "foundation stone of the native economic system". 49 Unsurprisingly, land loss had an extraordinary effect on Māori ability to provide adequately for their social and material well-being. There was, by the middle of the 19th century, a broad Māori understanding of their declining social position. The idea of poverty was expressed most clearly in connection with the experience of land loss.

An interesting and early example of the identification of Māori as "the poor" in a symbolic sense and constitutional context was in the birth of the idea for the Kingitanga, or the Māori King Movement. Mātene Te Whiwhi was reputed, in an 1862 account, to have suggested himself as an appropriate candidate for kingship: ${ }^{50}$

... haere ana ki ngā Rangatira o Rotorua kia whakaaetia ie hei kingi, a, kihai i painga. Ko te Mete Pakeha whakamaori o te Kawana i kite i taua hui huinga. E rua nga rakau i whakatu ai. He kakahu Maori i runga i tetahi, he kakahu Pakeha i tetahi, na, he kingi Maori he rawa kore, ko te Kuini, he mea whaitaonga, i reira ka mea atu a Te Heuheu ko Potatatu hei kingi ki waenganui o te Motu nei o nga iwi hoki.

While the primary driver for the establishment of the Kingitanga was to prevent further land loss, Māori welfare was inextricably linked to this concern. This awareness is reflected in the Southern Cross newspaper in 1858. Wiremu Tamihana Te Waharoa Tarapipipi explains, in translation, the recitation of Wiremu Te Akerautangi at one of the hui convened to debate the installation of Potatau as Māori King: ${ }^{51}$

The shame I feel is great

For thou has made a hapless exit.

And now thou art as fish caught from the sea

48 See Stephens, above n 35, at 834-836.

49 Raymond Firth Primitive Economics of the New Zealand (Revivals, Oxfordshire, 2011) 457.

50 "So he went to the chiefs of Rotorua to approve of his being nominated as King but his plan was not received. Mr Smith, interpreter to the Governor, was present at the meeting. Two sticks were stuck up with a Maori garment on one and a Pakeha garment on the other, the emblem of the Maori King representing poverty, that of the Queen wealth. It was then that Te Heuheu proposed Potatau as King in the midst of this island and people." Te Hokioi (13 June 1862), cited in Evelyn Stokes Wiremu Tamihana-Rangatira (Huia Publishers, Wellington, 2003) 138.

51 Wiremu Tamiha Southern Cross (New Zealand, 6 August 1858) cited in Stokes, above n 50, at 165. 
And placed upon the stalls to dry;

Are we to feed upon the things that come from lands far distant?

According to Tamihana's explanation, Wiremu Te Akerautangi: ${ }^{52}$

... feels shame that the sun of the Maori nation should have gone down. The present social condition of his countrymen is compared to fish once healthful swimming at ease in its native waters, but now ruthlessly cast upon the stalls no longer to be admired, but simply looked upon as an article of food. He asks whether the New Zealanders should be satisfied with the systems of foreign people which they

have been called upon to adopt.

In fact, many Māori engaged in a symbolic and mythological response to the crises of the 19th century, including social depredation due to land loss. ${ }^{53}$ In addition to the examples given, Māori often took on, and adapted elements of the Old Testament religious mythology that provided a uniting narrative. This narrative characterised Māori as the Jews wandering in poverty and in exile from their lands. Oppressed by the Pākehā as the Egyptians, Māori, with the aid of various prophets, sought the land of Canaan, flowing with milk and honey. ${ }^{54}$

By the middle decades of the 19th century Māori knew that the socio-economic well-being of all Māori collectives was already at dire risk as a direct result of land loss, and other factors such as disease and demographic change. The Crown knew this too, and that even the land that remained in Māori hands, due to the tenurial changes, often could not be developed in order to protect and develop Māori welfare.

In response, Māori had begun to develop solutions that would lift the socio-economic status of all or most Māori, primarily by addressing land loss and its grim companion, poverty.

\section{MATORI CIVIC ACTION TO ACHIEVE WELFARE}

The establishment of the Kingitanga provides one clear example where Māori were able to cohere to some degree, despite significant political contestation, across tribal lines to create a

52 At 165.

53 See Māmari Stephens "Ka whawhai tonu mātou: mythmaking and the preservation of identity among 19th century Māori and the Ancient Messenians" (LLB(Hons) dissertation, Victoria University of Wellington, 1997).

54 Among dozens of Māori prophetic movements, roots of the Ringatu religion, and the prophesies of Te Kooti Arikirangi, express this notion most clearly. See J Binney "The Ringatu Traditions of Predictive History" (1988) 33 The Journal of Pacific History 167 at 167-168. See also Bronwyn Elsemore Like Them That Dream: the Mãori and the Old Testament (Tauranga Moana Press, Tauranga, 1985); and Lachy Paterson "Maori 'Conversion' to the Rule of Law and Nineteenth-Century Imperial Loyalties" (2008) 32 Journal of Religious History 216. 
constitutional solution to try and make better social and political outcomes for Māori. ${ }^{55}$ Further exemplars illustrate more clearly how Māori subsequently sought, often through legislation, to create systems and rules that would secure political as well as social control over Māori welfare outcomes: ${ }^{56}$

- $\quad$ rūnanga of the 19th century;

- $\quad$ the Maori Councils Act 1900;

- the Maori War Effort Organisation; and

- the Maori Community Development Act 1962

A necessarily brief exploration of these exemplars also reveals that across the course of a century and a half, the idea of the "welfare" of the Māori has evolved somewhat. While always including the concern to combat social ills (including land loss and resultant poverty) to preserve basic physical and material well-being, the idea of "welfare" for Māori became the subject of a great debate as to how to use public power for achieving welfare ends. The process of acting collectively in order to secure sufficient power to achieve welfare was arguably viewed to be as important as the end goal of welfare itself. These concerns were, and remain, very different to those in the minds of the framers of the welfare state in the 1930s.

It is important to note that all of these exemplars faced political opposition within Māori communities, and even sometimes from Māori who were in government. The point of this review is not to illustrate whether such measures could politically unify Māori, although some came close. Neither is the point to examine or evaluate the efficacy of the measures put in place. Over the longer term, most failed. What this review illustrates is a consistent constitutional phenomenon comprising most, if not all, of the following factors:

(1) Negotiation between the Crown and Māori collectives to establish rules that enable Māori collectives to make their own decisions about achieving Māori welfare, however they defined that welfare.

(2) Māori collectives insisting on maintaining ongoing political relationships with the Crown in order to maintain a focus on achieving welfare for Māori.

(3) Māori within government often playing key roles in enabling the negotiations and relationship creation, and in the design of the systems.

(4) Māori collectives seeking to use these new systems in order to use decision-making power to affect Māori beyond their own immediate kin groups.

55 See Carwyn Jones "Whakaeke i Ngā Ngaru - Riding The Waves: Māori Legal Traditions and New Zealand Public Life" in Lisa Ford and Tim Rowse (eds) Between Indigenous and Settler Governance (Routledge, Abingdon, 2013) at 177.

56 There were many more Māori initiatives that could also have been included in this discussion but for want of space, such as the Kotahitanga movement and the Kotahitanga parliaments of the 1890s, the Repudiation Movement, and the Māori health councils of the 1920s and 1930s. 
(5) Māori collectives seeking mechanisms of representation and participation at executive levels of the systems being designed.

(6) Māori collectives seeking to establish mechanisms for "flax roots" participation from Māori communities.

\section{A Rünanga}

In the 1830s, 1840s and beyond, rūnanga and newly coined komiti (committees) were collective committees or group processes whereby decisions could be reached and disputes settled, with the use of tikanga Māori. ${ }^{57}$ Rūnanga were already well established as traditional collective decisionmaking gatherings. ${ }^{58}$ There are some extraordinary accounts, in mid19th century sources, of rūnanga being used by Māori as a way of making important political and social decisions over Māori lives. ${ }^{59}$ These fora allowed for the airing of new kinds of disputes and the public playing out of the contestable nature of those disputes. In fact, as noted by Fenton in 1857, the gathering and public participation by ordinary people, including women and children, in assembly was critically important to a functional Māori society. ${ }^{60}$

The rūnanga had, by the 1850 s, developed broader usage, even between hapu, or district-wide, adopting distinct processes influenced by European committee procedures. ${ }^{61}$ Such committees could be established relatively informally to combat land loss and restrict land sales. One Whanganui-based example saw a public meeting convened as a committee in 1877 which decided on the setting aside of a substantial tract of land for Māori reservation purposes as a way of avoiding inevitable poverty for the hapu from "all parts of the river": 62

The reason assigned for adopting such a course is an apprehension which exists amongst the Natives here (one founded on reason), that unless some steps are taken to check the wholesale alienation of land by the Natives, a danger exists of the owners thereof eventually disposing of the whole of their lands, thereby rendering themselves homeless and poverty stricken.

57 See for example Vincent O'Malley "English Law and the Maori Response: a Case Study From the Rūnanga System in Northland, 1861-65" (2007) 116 The Journal of The Polynesian Society 7.

58 Benton, Frame and Meredith, above n 45, at 429.

59 "He Tangi mō Tuwhare" in Apirana Ngata and Pei Te Hurinui Jones (ed) Ngā Moteatea: The Songs Part Three (Auckland University Press, Auckland, 2006) at 552-553.

60 Francis D Fenton "Report As To Native Affairs in the Waikato District, March 1857" [1860] AJHR E-1c at 11

61 A district wide rūnanga operated in Turanga for many years. See Vincent O'Malley "Reinventing Tribal Mechanisms of Governance: The Emergence of Maori Runanga and Komiti in New Zealand before 1900" (2009) 56 Ethnohistory 69 at 79.

62 "Woon to Assistant Native Secretary" [1872] I AJHR F-3A at 19, cited in Vincent O'Malley Agents of Autonomy: Maori Committees in the Nineteenth Century (Huia Publishers, Wellington, 1998) at 75. 
The Crown attempted to capitalise on these useful rūnanga-based processes by way of establishing the short-lived District Rūnanga System under the Native Districts Regulation Act 1858. ${ }^{63}$ Although this Act ultimately failed, as Adrienne Puckey notes, rūnanga-based processes remained to some degree, for example, in the far north: ${ }^{64}$

... behind these Māori initiatives were many hui, much korero, planning, initiating, promoting, arguing, negotiating and implementing, which indicate strong decision-making processes that were not recorded in writing. Māori did not abandon rūnanga and other traditional decision processes in favour of forms modified to Pākehā purposes. ... That the new institutions did not fulfil this purpose was not for want of effort on the part of Māori.

Forms of rūnanga as mechanisms of political participation were further seen with King Tawhiao's establishment of the Kingitanga's Kauhanganui, as a bicameral institution with its Council of the Twelve, which had its first sittings in the $1880 \mathrm{~s} .{ }^{65}$ Public gatherings were also important to the functioning and validation of the activities of the various Maori parliaments held between 1879 and the end of the 19th century. Over 300 attended the parliament called by Paora Tuhaere at Ōrakei in 1879, and over 1,000 individuals and 50 individual rangatira attended a hui in the Bay of Islands in 1892 to arrange the structure of the first Paremata Māori. ${ }^{66}$

The idea that rūnanga, with its powerful civic participation processes and the way such decisions could also be used to seek better social outcomes for broad groups, was also an important notion. These decision-making processes were also seen with the establishment of the Māori Councils Act 1900, and other subsequent developments. Māori built on rūnanga processes and placed themselves into positions by which Māori communities could have some control over achieving Māori welfare outcomes.

\section{B Māori Councils}

Clearly building on the successes of rūnanga and other similar participatory processes observed in the 19th century, the Maori Councils Act 1900 originally granted a limited amount of selfgovernance to Māori communities. Native Minister Sir James Carroll and the Young Māori Party had substantial input into designing this legislation, and the Maori Lands Administration Act 1900,

63 Other attempts to "connect" the traditional rūnanga to formal government bodies included the Native Councils Bill 1860, Native Committees Act 1883 and the Native Land Administration Act 1886. The Maori Councils Act 1900 too can be seen as descended from those earlier efforts.

64 Adrienne Puckey "The substance of the shadow: Māori and Pākehā political economic relationships, 18601940: A far northern case study" (PhD Thesis, University of Auckland, 2006) at 137-138.

65 Angela Ballara "Te Kīngitanga: The People of the Māori King Movement" in The Dictionary of New Zealand Biography (Auckland University Press, Auckland, 1996) 9.1.

66 Lindsay Cox Kotahitanga: The Search For Māori Political Unity (Oxford University Press, Auckland, 1993 ) at 66-68. 
which set up Māori land councils, controlled by Māori, which could sell or lease Māori land. Apirana Ngata was one of the main drafters of both Bills and also of the model for council bylaws. The councils were not universally supported; the Kingitanga suspected the Crown of seeking to use them to undermine broader kotahitanga (and including, therefore, the operation of the Kotahitanga parliaments of the 1890s) as well as the Kingitanga's own Kauhanganui. ${ }^{67}$ Such tensions often occurred between the Crown and the various Māori political movements. ${ }^{68}$

Under the Maori Councils Act 1900, 30 councils were set up with more than 200 village committees. The preamble of the Act illustrates the Crown goal that Māori be ushered into "higher civilization", with the guiding notion of enabling Māori to look after their own socio-economic needs ${ }^{69}$

WHEREAS reiterated applications have been made by the Maori inhabitants of those parts of the colony where the Maoris are more or less domiciled and settled, forming what is known as Maori centres and surroundings, for the establishment within those districts of some simple machinery of local selfgovernment, by means of which such Maori inhabitants may be enabled to frame for themselves such rules and regulations on matters of local concernment or relating to their social economy as may appear best adapted to their own special wants $[\ldots]$

This Act also provided the councils with the power to regulate matters pertaining to health and welfare in their specific areas, including for: ${ }^{70}$

(1) For the providing for the health and personal convenience of the inhabitants of any Māori village, pa, or assemblage of houses.

(2) For enforcing the cleansing of houses and other buildings in dirty and unwholesome state.

(3) For the suppression of common nuisances.

(4) For the prevention of drunkenness and sly-grog selling.

The councils dealt with dog registration, the branding of cattle, registration of tohunga, the water supply, schools, sanitation and general social matters. Of direct relevance to modern understandings of the precursors to social security, the councils were also expected to exercise authority over the maintenance and support of illegitimate children: ${ }^{71}$

67 Richard Hill State Authority, Indigenous Autonomy: Crown-Māori Relations in New Zealand (Victoria University Press, Wellington, 2004) at 52.

68 See particularly Cox, above n 66 .

69 Maori Councils Act 1900, preamble.

70 Section 16.

71 Section 22 
The Council shall, in order that provision shall be made for the proper maintenance and support of illegitimate children, or children known according to the Maori custom as poriro, on the discovery of the father of any such child, compel him to make such weekly payment or such other provision for the support of such child as it may deem fit, or to require security for the proper payment of such maintenance.

At any time when requested so to do by the Council, or when it is deemed expedient, the Governor may, as therein provided, declare that "The Destitute Persons Act, 1894," shall be brought into operation in any Maori district.

This provision is significant to the extent that it acknowledges that there already existed a system for issuing maintenance orders against the parents of illegitimate children, consolidated in the passage of the Destitute Persons Act 1894. Section 2 of that Act provided that it would come into effect "in respect of persons of the aboriginal native race in such districts and at such times as the Governor shall from time to time appoint". Nevertheless, the operation of that section is suspended until such time as either a Māori council requested it, or the Governor issued a declaration. This "opt in" provision provides an interesting example of the presumption that Māori provision of financial assistance to their families would continue to operate outside of the legislative system.

The councils were effective for some years, but they were largely obsolete by the 1920s. They never fulfilled their potential, largely because they were hopelessly under-resourced, but also because the strictures placed on the operation of the councils frustrated their efficacy. ${ }^{72}$ In addition, land loss (by way of compulsory vesting of "unrequired" or "unleased" Māori land) had continued under the Māori lands administration scheme, also initiated in 1900 and amended in $1905 .{ }^{73}$

Despite their obvious limitations, and the continued loss of Māori wealth in the 1890s and early decades of the $1900 \mathrm{~s},{ }^{74}$ the councils provide a strong example of Māori seeking to exercise civic decision-making power, including formal by-law making, often with improved Māori welfare in view. The councils were participatory, and sought to be broadly representative. Sir James Carroll championed their development within government, as did Apirana Ngata once in Parliament from

72 See Hill, above n 67, at 62 .

73 That scheme was set up under the Maori Lands Administration Act 1900 and had initially sought to give Māori more control over the alienation of Māori land. However the Maori Lands Settlement Act 1905 replaced the former Māori Land Councils established in 1900 with Māori Land Boards with members to be appointed by the Crown, with at least one of the three members to be Māori. Much more "unrequired" or "unleased" lands were then vested in these now European-dominated Boards.

74 Keith Hooper and Kate Kearins "The walrus, carpenter and oysters: Liberal reform, hypocrisy and expertocracy in Maori land loss in New Zealand 1885-1911" (2008) 19 Critical Perspectives on Accounting 1239 at 1254 . 
1907, and they had a broad welfare agenda, involving local bodies taking enforceable decisions. The experience of the councils, and their later loss, would prove influential on subsequent initiatives.

\section{Māori War Effort Organisation}

The Second World War prompted the growth of another critically important Māori organisation concerned with using decision-making power to achieve welfare outcomes for very large numbers of Māori: the Māori War Effort Organisation (MWEO). This entity has been dubbed the crowning achievement of the Rātana-Labour alliance. ${ }^{75}$ Under the administration of the first Rătana Cabinet Minister, PK Paikea, the MWEO took upon itself the task of recruiting Māori to be part of the war effort, leading to the establishment of the Māori Battalion (mainly along tribal lines). ${ }^{76}$

The War Cabinet initially established the MWEO for six months. By the end of that time, and after a series of meetings of hapu and iwi leaders, the MWEO comprised 21 districts and more than 300 tribal committees. It became "the largest tangata whenua organisation ever to be established under Crown auspices". ${ }^{77}$ This extraordinary development had enormous and widespread Māori community support. ${ }^{78}$ The MWEO also continued the work of earlier bodies: ${ }^{79}$

Before long, moreover, many of the committees were taking on the functions of local bodies, assuming powers previously exercised by the Maori Councils/Maori Health Councils and their village committees (a few of which continued a separate existence outside the MWEO, though in relation to it). They did so 'with considerable success' - not only from their own perspective but also, at times, from that of the state.

The MWEO facilitated a good deal of welfare work that village committees carried out with considerable success and efficiency. ${ }^{80}$ The MWEO used collective approaches to improve Māori employment, land productivity and food production. From 1943 onwards the MWEO was

75 Tiopira McDowell "Te Ana o te Raiona: Māori Political Movements and the Māori Seats in Parliament, 1867 - 2008" (PhD Thesis, University of Auckland, 2013) at 137.

76 The MWEO was extraordinarily successful in this aim. Within a very short period of time, the MWEO had, according to Hill, enlisted 5178 men for overseas war service, 2088 for home-based military service and 10,229 for the Home Guard; a total of 17,495 enlistments. See Hill, above n 67, at 193.

77 At 193.

78 Claudia Orange "An Exercise in Maori Autonomy: The Rise and Demise of the Maori War Effort

Organization" in Judith Binney (ed) The Shaping of History: Essays from The New Zealand Journal of History (Bridget Williams Books, Wellington, 2001) 62 at 75, cited in the Waitangi Tribunal Whaia te Mana Motuhake: In Pursuit of Mana Motuhake: Report on the Māori Community Development Act Claim (Wai2417, pre-publication version, 2014) at 84-85.

79 Hill, above n 67, at 193.

80 "50 Years of Maori Self Government" Te Ao Hou: The New World (New Zealand, Winter 1952) at 23. 
expanded, and commenced advising Māori receiving payments under the Social Security Act 1938 how best to use those payments. It established "lady welfare officers" to assist Māori women who had shifted to the poorer areas of larger towns and cities. ${ }^{81}$ These officers were the early precursors to the Māori Women's Welfare League, established in 1951.

The end goal of improving Māori social life and welfare, particularly in the context of urbanisation, was becoming more closely linked with the MWEO's ability to make effective decisions for, and on behalf of, Māori. In effect, the MWEO did what no other Māori initiative had been able to manage: successfully marry broad-based Māori political unity with civic whanaungatanga. It united iwi-based and pan-Māori organisations, and facilitated decision making relevant to the welfare of all Māori, to varying degrees. Both Tennant and Orange describe the MWEO as establishing independence and self-governance for Māori. ${ }^{82}$ It also had very close, if not always formal, links to the machinery of government; it had its own parliamentary committee and its own minister (PK Paikea). ${ }^{83}$

\section{Changing ideas of "welfare"}

By the war's end, Māori had very high expectations that they would be able to benefit from their incorporation into full social and political New Zealand citizenship, having paid a terrible price in war casualties. ${ }^{84}$ According to Margaret Tennant, the idea of welfare had, by this time, become closely linked for many Māori now in the cities to notions of urban community development and capacity building, as well as the relief of social ills including poverty. Similar to the conflicts between different visions of unity in Māori political activism in the 19th century, further tensions arose as Māori debated who ought to be responsible for welfare and what welfare now meant. Should the Native Affairs Department lead development, or more independent Māori organisations? ${ }^{85}$ Was welfare still intimately connected to land usage, and the survival of culture and community, or could welfare be disconnected from those bedrock things? For many Māori who

81 Hill, above n 67, at 193.

82 Claudia Orange "An Exercise in Māori Autonomy: The Rise and Demise of the Māori War Effort Organisation" (1987) 21 New Zealand Journal of History 157 at 159-160, cited in McDowell, above n 75, at 138; and Margaret Tennant The Fabric of Welfare: Voluntary Organisations, Government and Welfare in New Zealand, 1840-2005 (Bridget Williams Books, Wellington, 2007) at 89.

83 As outlined in the Waitangi Tribunal, above $\mathrm{n} 78$, at 80

84 Ministry for Culture and Heritage "Māori and the Second World War: Page 2 - Response to War" (20 December 2012) New Zealand History <www.nzhistory.net.nz>. See also Paul Meredith "Urban Maori as 'New Citizens': The Quest for Recognition and Resources" (paper presented to Revisioning Citizenship in New Zealand Conference, University of Waikato, February 2000).

85 Margaret Tennant "Welfare Interactions: Māori, Government and the Voluntary Sector in New Zealand" (2005) 2 History Australia 80.1 at 80.9-80.10. 
moved to cities during urbanisation, the idea of their welfare now inevitably included development in an urban context, connected less with land and the survival of a community of origin: ${ }^{86}$

For Maori, "welfare" has always involved issues of land and culture maintenance ... In the post-World

War II era, it was defined for them as "development" and adjustment to living in a modern urban

environment, and the Department of Maori Affairs had a wide mandate in terms of land development,

employment, welfare and social services.

As Humpage also noted, successive governments used the institutions of the welfare state to encourage Māori to urbanise in order to facilitate development of the post-war urban economy: "Welfare state institutions were used to facilitate this shift through relocation programmes (including access to state housing rentals) and redirection of economic assistance from rural to urban areas." 87

As the post-war period progressed, so did these two notions of welfare for Māori. On the one hand, Māori living in tribal areas still wanted to make decisions for their own communities, centred on iwi and hapū populations, often facilitating land management and development. On the other hand, Māori in the cities still required cultural connection to their communities of origin, and to make their own decisions about how to adjust to the new urban world.

\section{Mäori Social and Economic Advancement Act 1945}

By the end of the War, the time of the MWEO had come to an end. In the hope of retaining the MWEO momentum, Rātana MPs Eruera Tirikatene and TP Paikea (replacing his father PK Paikea, who had died unexpectedly in 1943) formed a Committee to create and promote appropriate legislation. The Prime Minister Peter Fraser, who initially held ministerial responsibility for the Committee, and who later also took on the portfolio of Native Affairs, had also been instrumental, alongside Walter Nash and Savage, in the passage of the Social Security Act 1938. Tirikatene and Paikea drafted early versions of the Māori Social and Economic Advancement Bill, which was supposed to herald a new dawn of more formal Māori cooperation and involvement in decision making with the state, including the Native Affairs Department. The new representation system was intended to echo, if not copy, the tribal executive/tribal committee-based approach of the MWEO, although it would be grounded within the departmental structure. Key to the success of this new structure would be the continued ability of Māori communities, including marae, to have input into

86 At $80.9-80.10$.

87 Louise Humpage "Revisioning comparative welfare state studies: an 'indigenous dimension'" (2010) 31 Policy Studies 539 at 542. 
higher decision-making processes, or as Hill put it: "flax-roots influence on decision making". ${ }^{88}$ As Hill notes: ${ }^{89}$

In particular, it was crucial that the reconstituted bureaucracy heed the views of Maori at community and marae level, via tribal committees. The draft legislation provided for each of these to select two delegates to a tribal executive, as with the MWEO. But the executive in turn would elect a delegate to one of four district councils. The latter were to be a senior-level mechanism for passing flax-roots views onto the country's decision makers, and so would also contain representatives from the bureaucracy and Parliament. Each district council would elect two of the members of a Board of Maori Social and Economic Reconstruction, which would also include officials and politicians.

Peter Fraser appeared to consider that something of the MWEO had to be preserved under the new legislation in order to foster Māori autonomy and Māori development. He expressed the risks posed by mere absorption into the Native Affairs Department structure: $9^{90}$

It was early recognised by myself that if the Organisation was absorbed into the ordinary activities and routine of the Department it would to a very great extent, be stultified and could not possibly exercise that positive beneficial influence, and carry out the work specified by Parliament for it to do as efficiently as if it was practically an autonomous organisation. It has been my aim to make the Organisation as self-controlling and autonomous as possible, that is to the full limits of its potential development - always stipulating for efficiency. ... The Māori Social and Economic Welfare Organisation must not be looked upon as merely another branch of the Māori Department. It is an organisation that must be to a very large extent independent and self reliant. The Tribal Committees, the Tribal Executives and the Welfare Officers must think out proposals and plans for the advancement of the Māori people in all directions ...

The full title of the Maori Social and Economic Advancement Act 1945 was: "An Act to make Provision for the Social and Economic Advancement and the Promotion and Maintenance of the Health and Social Well-Being of the Māori Community." This language is similar to the socially democratic notion of maintaining and promoting "the Health and General Welfare of the Community" as set out in the Long Title to the Social Security Act 1938.

It is jarring, therefore, that despite Fraser's fine words above, the resulting statute was stripped of the crucial elements that his own Māori MPs had provided for in the Bill, including the critically important district councils, and any provision for national representation. Instead, the tribal

88 See Hill, above n 67, at 212.

89 At $210-211$

90 "Fraser to Under Secretary, 21 September 1948" (as quoted in Orange, above n 78, at 73-74), cited in Waitangi Tribunal, above n 78, at 82 . 
executives themselves were incorporated into the Department structure with departmental welfare officers installed on each executive. ${ }^{91}$

Some limited opportunities for grassroots involvement in Māori welfare remained, and for this reason the 1945 Act has been called a "partial victory". 92 The Act provided a degree of freedom for the lower level committees to operate relatively freely. Further, the passage of the Act led to the replacement of the old Native Affairs Department with the Department of Māori Affairs, which took over the administration of Māori welfare officers, and directly encouraged the establishment of the Māori Women's Welfare League. ${ }^{93}$ By April 1954, the League had become an extraordinary community-based initiative, had grown to 303 branches under 64 district councils and was primarily focused on Māori development in the areas of health, education, justice and housing. ${ }^{94}$

However, the opportunity for Māori to use decision-making (and representative) power to make executive decisions on how best to achieve Māori welfare outcomes within a legislative framework was cauterized. ${ }^{95}$

\section{E Māori Community Development Act 1962}

Despite the negotiations between Māori communities and the Crown that underscored the development of the MWEO, the final form of 1945 Act was a disappointment. The deliberate exclusion of Māori executive power from the 1945 Act's structure had to be rectified. What was needed was a district and national council framework. ${ }^{96}$ It took many more years of negotiating between Māori leaders and reluctant Labour and National governments, and the informal creation of Māori district councils, before this framework came to be.

Nevertheless, by the late 1950s a head of steam had developed for the creation of a new legislated framework of district councils and a national council. In 1959 a deputation of Māori leaders formally requested the legislative creation of the new council system. Major Henry Te Reiwhati Vercoe, Chairman of Te Arawa Tribal Executive, spoke of the constitutional importance of such a body: 97

The importance for Māori that a channel be created through which "we can come to you with the matters of our various districts and of our Māori people as a whole, coming with matters screened and

91 See Waitangi Tribunal, above n 78, at 84-85.

92 Orange, above n 78, at 72-73.

93 See Tennant, above n 85, at 80.1-80.2.

94 See Waitangi Tribunal, n 78, at 94-100.

95 See Hill, above n 67, at 186 and following.

96 See Waitangi Tribunal, above n 78, at 88-89.

97 "Deputation to the Prime Minister, 9 December 1959", cited in Waitangi Tribunal, above n 78, at 108. 
vetted by our councils". This would benefit the Government as well as Māori because it would speed up the welfare work, and the Minister (and Parliament) could rely on it as the voice for the whole of the Māori people.

The councils would embody Māori democracy and provide a body to speak to the Crown with the authority of that democracy at a national level.

Labour Māori MPs, who feared a National-influenced body that could undermine their own role in Parliament, did not support the proposal. Consequently the new council structure was not placed on the legislative agenda until 1962, after Labour had lost office. In 1961 a Provisional Dominion Māori Council was set up, and collaborated with the Government in drafting the new legislation. This became the Maori Social and Economic Advancement Amendment Act 1961, establishing the new council framework. In introducing the Bill, the Minister of Māori Affairs stated, somewhat optimistically: ${ }^{98}$

This Bill will help the Māori people to govern their own affairs to a large extent, and to preserve the important features of Māoritanga, the language, arts and crafts, and institutions of the marae. This Bill gives the Māori people the statutory form to work out their own salvation, and I only wish we could have more debates of this class, where we are concerned with the welfare of a section of the community without any question of one side [of the House] or the other seeking political advantage.

Negotiations between Māori leaders and the Crown continued about the shape and functions of the new council framework, culminating in the Maori Welfare Act 1962, now known as the Community Development Act 1962. The Waitangi Tribunal, in its 2014 Report on the Māori Community Development Act Claim, affirmed that the Crown and Māori did enter into a negotiated agreement prior to the enactment of the 1962 legislation. The 1962 Act established 14 district Māori councils and a national council. Like the old Māori councils of the early-20th century, and the tribal committees of the 1940s and 1950s, these new bodies also had welfare objectives, as set out under s 18:

18(1) to promote, encourage, and assist Maoris

(i) to conserve, improve, advance and maintain their physical, economic, industrial, educational, social, moral, and spiritual well-being;

(ii) to assume and maintain self-reliance, thrift, pride of race, and such conduct as will be conducive to their general health and economic well-being $[\ldots]$

98 Hon Ralph Hanan, Minister of Māori Affairs, regarding the enactment of the Maori Social and Economic Advancement Amendment Bill 1961: "This Bill gives the Māori people the statutory form to work out their own salvation ...": (1961) 327 NZPD 1982. 
Whereas the Maori Social and Economic Advancement Act 1945 required that each tribal executive include one Native Affairs Department Welfare officer, that relationship was modified under the 1962 Act. Responsibility for Māori welfare was, it seemed, to devolve onto the shoulders of the new Māori district councils, although with ongoing cooperation from the welfare division of the Māori Affairs Department. ${ }^{99}$

Indeed evidence strongly suggests that many Māori committees under the New Zealand Māori Council structure carried out significant welfare assistance among Māori communities in the 1960s and 1970s. Of special note were urban Māori committees, which were instrumental in assisting Māori families to adjust to urban living. By 1966, 33 such committees had been established in Auckland alone, taking on tasks such as mediating landlord/tenant relationships, providing budgetary advice, undertaking prison work, overseeing Māori wardens, establishing urban marae and carrying out a host of other activities merely labeled "welfare work". ${ }^{100}$ In addition, the Māori wardens, formally recognised under the Maori Social and Economic Advancement Act 1945, had their powers and functions transferred to the Community Development Act 1962, and came under the supervision of the district Māori councils. ${ }^{101}$ Wardens carried out a range of very diverse functions among Māori communities, at least some of which could fit a broad notion of welfare, such as patrolling streets and gatherings, assisting young people in need, providing budgeting assistance and supporting beneficiaries with government agencies. ${ }^{102}$

At the same time as local committees were carrying out, or supervising, these broad welfare functions at the flax-roots level, the early-1960s revealed that the National Council was indeed heavily involved in an important constitutional role: perusing and approving legislation. The Rătana MP for Eastern Māori, Tiaki Ōmana, affirmed the constitutional impact of the role for the National Council in a comment made to a meeting between the council and the Māori MPs. He described the Council as the "Ombudsman of the Māori Race". This comparison was a timely one, and scarcely accidental; former minister of Māori Affairs, Hon Ralph Hanan, now Minister of Justice, was then overseeing the passage of the Parliamentary Commissioner (Ombudsman) Act 1962.

The annual reports of the Department of Māori Affairs showed that officials expected that all legislative changes relevant to Māori would be passed to the Council for "approval". In addition, the Council would also review legislative proposals. The Council reviewed proposals and bills

99 See Waitangi Tribunal, above n 78, at 145.

100 See at 182.

101 See at 298.

102 See at 292-297. 
pertaining to eradicating discrimination in juries, the Māori Education Foundation, amendments to the criminal law and Māori land titles, to name a few. ${ }^{103}$

The council system has remained in place since the 1960s, but in reality it has been progressively denuded of resources. The Waitangi Tribunal has found that the operation and effectiveness of the Council has been effectively stymied due to underfunding, in breach of the principles of the Treaty of Waitangi. ${ }^{104}$ In recent decades, the Crown has shifted its mode of consultation, preferring to deal with tribal rūnanga, and the Tribunal acknowledged that the Council now continues to function in a "changed representational landscape", 105 and even its involvement with Māori wardens has become highly problematic. ${ }^{106}$ In the wake of the 2014 Tribunal Report, and its recommendation for review of the system, it is not clear what the future of the New Zealand Māori council will be, nor that of the council system as a whole, either as a system of representation, or as a means of achieving welfare ends for Māori.

Nevertheless, as with earlier initiatives, the council system was considered to be an important mechanism for engagement with the Crown, and was important to Māori in the drive to achieve welfare ends by means of a particularly Māori vision of constitutionalism.

\section{CONCLUSION}

Part V outlined some examples of Māori civic collectivism that sought to achieve better Māori welfare outcomes for Māori in traditional and urban environments. All of these initiatives met with some significant initial success, but not one of them has been able to maintain that success over a long period of time. However, they all show a common and consistent concern that Māori be able to exercise decision-making power in such a way that Māori be able to provide their own means of achieving some degree of welfare, or well being for Māori communities, including those beyond their own immediate kin connection.

Over the course of well over a century, Māori consistently sought to cohere across tribal divisions to make decisions for themselves and other Māori in order to bring about competing visions of "welfare" for Māori. Māori have created bodies (rūnanga, committees, local councils and executive organisations), charged with welfare responsibility. These bodies have often included provision for public participation such as elections and conferences. These bodies have also sought to have sufficient power to make decisions about resources, actions and rules that would be followed by Māori communities, even where the bodies have not sought to use those powers (as in the case of the power to make district Māori council bylaws). Māori have successfully and

103 See at 183.

104 See at 520 .

105 See at 242 .

106 See at 242 . 
continuously negotiated with the Crown in different time periods to claim sufficient space for these bodies to make those decisions, and often that space has been won through legislation. Often, but not always, for such initiatives to gain traction, senior Māori members of the government such as Carroll, PK Paikea and Tirikatene, have needed to champion the measure and create political pressure. All of these initatives sought an ongoing relationship, and ongoing intense negotiation with the Crown, and to a lesser or greater degree, with the bureaucracy of the Māori Affairs Department.

The welfare constitutionalism outlined in this article differs in character from that which can be argued to have underpinned the establishment and maintenance of the welfare state in its focus on Māori collective entities and a consistent concern to ensure "flax-roots" Māori participation in decision making.

As mentioned in the introduction, the SMP of the Tūhoe Treaty settlement, as concluded in 2014, sets the scene for the creation of a "Tūhoe Welfare System", in negotiation and with the support of government agencies. Such a system will likely sit easily alongside the initiatives mentioned in this article. The SMP envisages Māori communities and families will seek to exercise agency in the provision of welfare outcomes. It also involves the creation of structures, but also a certain degree of limited autonomy, largely free of legislative control, to allow Māori collectives a degree of freedom within which to exercise tikanga in order to bring about better welfare outcomes for Māori. Rather than isolated, or merely "modern" developments, this initiative will likely be the latest in a long line of attempts by Māori to exercise a distinctive Māori welfare constitutionalism. 